\title{
AMINO-ACIDURIA AND COPPER METABOLISM IN HEPATOLENTICULAR DEGENERATION
}

BY

J. D. SPIllane, J. W. KEYSER, AND R. A. PARKER

From the Departments of Neurology and Neurosurgery and of Pathology and Bacteriology, Welsh National School of Medicine, Cardiff

(RECEIVED FOR PUBLICATION JULY 30, 1951)

There is no doubt about the importance of the discovery by Uzman and DennyBrown (1948) of severe and persistent amino-aciduria in a case of hepatolenticular degeneration. No evidence of renal disease was found in their case, and there was neither clinical nor laboratory evidence of hepatic cirrhosis. It was therefore natural to consider the possibility of there being a fundamental defect in the metabolism of amino acids in this disease. The condition is distinguished from the Fanconi syndrome, which shows amino-aciduria but has other associated metabolic disorders. Uzman and Denny-Brown's patient was suffering from the mildest form of the disorder, and liver biopsy showed that the lobular arrangement was somewhat distorted but that there was no definite increase of the connective tissue in the portal areas. A brother was similarly afflicted, but biochemical studies were not made.

Porter (1949) also found that in three cases of the disease there was consistent amino-aciduria, and that in examples of diseases such as Huntington's chorea, paralysis agitans, dystonia musculorum deformans, and familial spastic paraplegia no such abnormality was present. Eckhardt, Cooper, Faloon, and Davidson (1948), at about the same time as Uzman and Denny-Brown, reported that five cases of Wilson's disease excreted in the urine greater amounts both of $\alpha$-amino nitrogen and of 10 " essential " amino acids than did eight normal subjects. Seven patients with severe liver disease showed considerable individual variation in amino acid excretion, with an average not much above that of the normals.

The same group of workers (Cooper, Eckhardt, Faloon, and Davidson, 1950) confirmed the presence of amino-aciduria in six cases of hepatolenticular degeneration. They also found that their patients had on the average a slightly higher fasting plasma $\alpha$-amino nitrogen concentration than did the normals. This was inconstant, however, and no correlation could be demonstrated between the aminoaciduria and the plasma amino nitrogen concentration. All of their patients had some indication of liver disease, although in only one was it severe. Again, there was no correlation between the extent of the amino-aciduria and the severity of the liver disease. They found, by contrast, that other, control, patients with moderate or severe cirrhosis of the liver did not have increased excretion of amino acids in the urine. They inferred that to attribute the amino-aciduria in hepatolenticular degeneration to the hepatic involvement it would be necessary to assume that the variety of liver abnormality is distinctly different from that of ordinary cirrhosis. 
It would also be an unusual hepatic defect that resulted in amino-aciduria without elevating the plasma amino nitrogen concentration.

Cooper and his colleagues found that the rapid infusion of amino acids to their patients with hepatolenticular degeneration did not result in a significantly greater loss of amino acids than in normals. There was no demonstrable defect of intermediary amino acid metabolism. The persistence of the amino-aciduria in the fasting state suggested to them that there was a lowered renal threshold for amino acids. In three of their patients there was renal glycosuria, and another patient presented evidence of deranged calcium and phosphorus metabolism and osteomalacia. They concluded that the kidney was probably the site of the defect resulting in excessive amino acid loss, but the type of abnormality remains unexplained. It is possible, however, as suggested by Cooper and his colleagues, that some abnormality in the kidney would lead to a loss of one or more substances necessary for the normal function of brain and liver.

In the muscular dystrophies generalized amino-aciduria has been recorded by Ames and Risley (1948), but it there appears to be a reflection of the severity of the disease and the extent of the muscular wasting.

A second abnormality that may be present in hepatolenticular degeneration consists of an increase in the copper content of both brain and liver (Haurowitz, 1930 ; Glazebrook, 1945 ; Cumings, 1948). Glazebrook found in his case that the blood and liver copper were respectively $0.30 \mathrm{mg}$. $/ 100 \mathrm{ml}$. and $4.6 \mathrm{mg}$./ $100 \mathrm{~g}$. (presumably wet tissue). He also considered that the figures for the copper content of cerebral cortex and basal ganglia were elevated. Cumings, in three cases that came to necropsy, found that in each there was an increased copper content in the brain and liver. His figures were (mg./100 g. dry tissue) :

\begin{tabular}{|c|c|c|c|c|c|c|c|}
\hline Cortical white & natter & & & & 10.9, & 14.7, & 12.9 \\
\hline Cortical grey $\mathrm{m}$ & atter & & . & $\cdots$ & 4.6 & 27.6, & 46.5 \\
\hline Caudate & . & . & . & . & 10.1, & 31.8, & 13 \\
\hline Thalamus & .. & • & . & .. & 31.9 , & 20.7, & 1.5 \\
\hline Putamen & .. & • & . & . & - , & 60.5, & 69.3 \\
\hline Globus pallidus & .. & • & . & .. & 8.4, & 23.0, & 39.9 \\
\hline Liver $\quad \ldots$ & .. & . & .. & .. & 156.4, & 55.0, & 39.4 \\
\hline
\end{tabular}

Normal figures for copper in brain and liver tissue found by Cumings are as follows (mg./100 g. dry tissue) :

\begin{tabular}{|c|c|c|c|c|c|c|}
\hline \multicolumn{2}{|c|}{ Cortical white matter } & & & & & $1.1-8.2$ \\
\hline \multicolumn{2}{|c|}{ Cortical grey matter } & & & & & $2.4-9.9$ \\
\hline Caudate $\quad \ldots$ & . & - & . & . & . . & $3.4-9.4$ \\
\hline Thalamus & .. & . & . & .. & .. & $3.1-12.4$ \\
\hline Putamen $\quad$. & .. & .. & .. & .. & . & $6.1-12.0$ \\
\hline Globus pallidus & ․ & . & .. & .. & .. & $10.5-18.8$ \\
\hline Liver & . & & & & .. & $3.7-17.2$ \\
\hline
\end{tabular}

Mandelbrote, Stanier, Thompson, and Thruston (1948) found that in one case of the disease which they studied there was a very high urinary excretion of copper $(41.7 \mu \mathrm{g} . \mathrm{Cu}$ in one two-hour period) and that, as in normal persons, the administration of B.A.L. (2, 3-dimercaptopropanol) greatly increased copper excretion (109 $\mu \mathrm{g}$. $\mathrm{Cu}$ in two hours). Porter confirmed the presence of increased urinary excretion 
of copper in two cases of hepatolenticular degeneration and found that the administration of B.A.L. sufficient to increase the copper output by sevenfold did not significantly alter the amino-aciduria.

Quite recently Cumings (1951) has reported an investigation of four patients with hepatolenticular degeneration. In two cases showing an increased urinary output of both amino nitrogen and copper the administration of B.A.L. produced an increase in the urinary copper output, but the amino nitrogen was unaffected. These two patients improved clinically during treatment. In the two other cases, one showing a raised nitrogen and a normal copper and the other a normal amino nitrogen and somewhat raised copper output, B.A.L. had no effect on either urinary copper or amino acid excretion and neither patient improved clinically.

We present the results of an investigation of amino acid excretion and of copper metabolism in one case of hepatolenticular degeneration which came to necropsy. During life there was little evidence of liver disease, yet when the patient died hepatic cirrhosis was found. Amino acid excretion was also studied in 12 cases of other disease of the basal ganglia.

\section{Material and Methods}

Thirteen patients were investigated. These comprised one case of hepatolenticular degeneration (Case 1), four cases of Huntington's chorea, six cases of dystonia musculorum deformans, and two cases of congenital choreo-athetosis. In all of these cases amino nitrogen excretion was measured. Two of the patients suffering from dystonia (Cases 4 and 7) closely resembled clinically the fatal case of hepatolenticular degeneration. Copper excretion was investigated in Case 1 and the copper content of tissues was estimated after death.

Urinary amino nitrogen was estimated by the method of Pope and Stevens (1939) applied to urine by Albanese and Irby (1944). Twenty-four-hour collections of urine were made in bottles each containing $1 \mathrm{ml}$. of $10 \%$ alcoholic thymol and $50 \mathrm{ml}$. of approximately $1.5 \mathrm{~N}$ hydrochloric acid. Copper in urine and tissues was estimated colorimetrically with diethyldithiocarbamate (Eden and Green, 1940). Urine for this estimation was collected in bottles that had been cleaned by washing with acid and finally with glass-distilled water. No metal was allowed to come into contact with tissues to be analysed for copper, which were cut with a sharp piece of glass, though unavoidably blood had to be taken through metal (stainless steel) needles. Serum total protein and albumin (Howe, 1921) were estimated by the micro-Kjeldahl method ; serum bilirubin with the Lovibond comparator; serum alkaline phosphatase as described by King (1946) ; serum colloidal gold using the buffered gold sol of Maclagan (1944a) as described by Pollak (1947); and blood prothrombin as described by Aggeler, Howard, Lucia, Clark, and Astaff (1946), but using 0.02M calcium chloride as recommended by Quick (1945). The thymol (Maclagan, 1944b) and zinc (Kunkel, 1947) turbidity tests were also performed.

\section{Case Notes and Results}

Case 1 : Hepatolenticular Degeneration.-This boy, aged 14 years, was an only child. No significant abnormality was recorded in a full study of the family tree.* Both parents

* Including all members of the family as far back as the patient's grandparents and his grandmother's brothers. 
were alive and well and showed no evidence of disease. The only previous illness of note was an attack of jaundice at the age of 7 years. The patient was of good physical and mental development until the age of 10 years. He then began to find difficulty in using his arms and legs properly : " he kept on falling about." He became hysterical at times. His movements were clumsy and tremulous and eventually he could not write. He found speaking increasingly difficult and he could not close his mouth. At times he had severe pains in the shoulders and arms. On examination he presented the typical features of the disease. He was emotional and showed the characteristic grinning expression with tight mouth and bared teeth. There was a well-marked Kayser-Fleischer ring in each eye (Fig. 1), speech was practically incoherent and writing

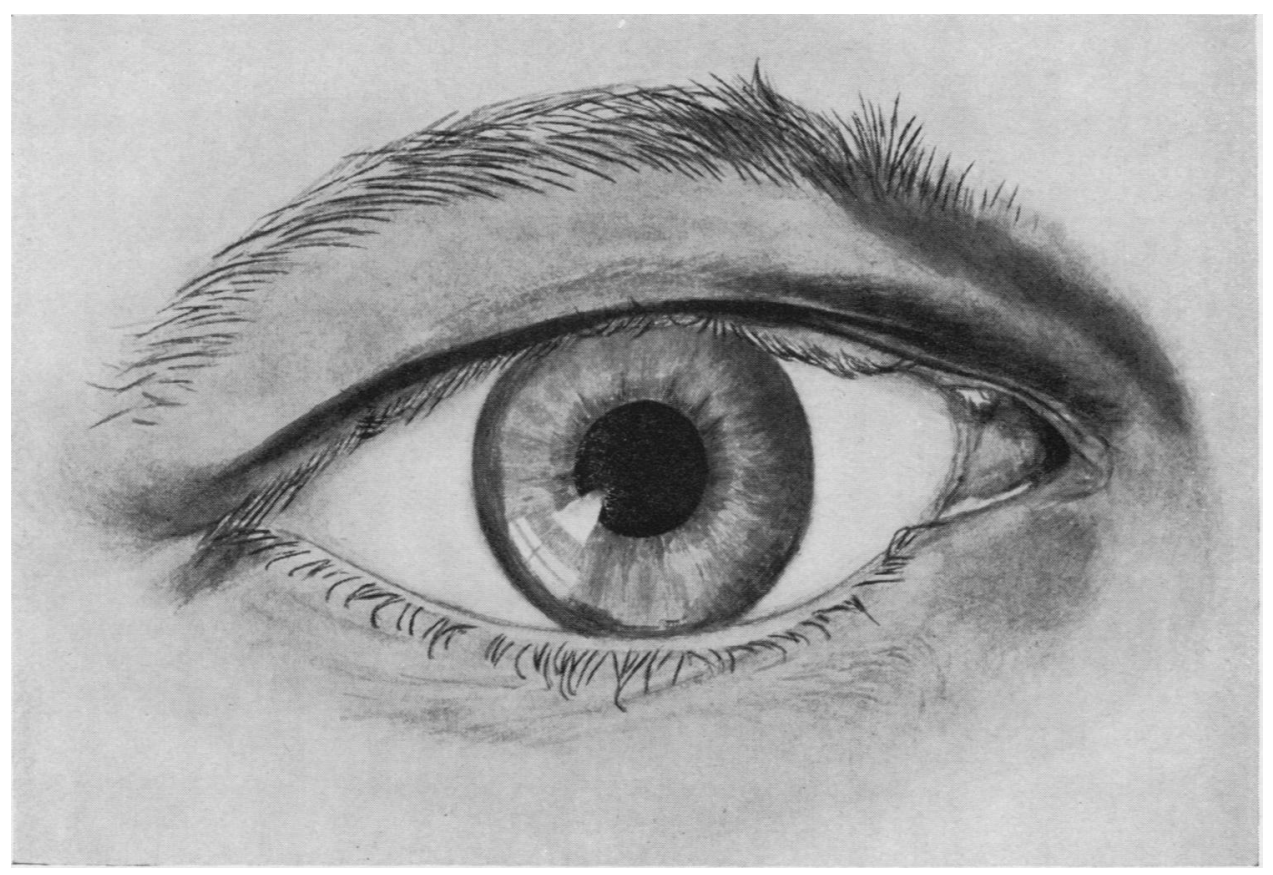

FIG. 1.-Kayser-Fleischer ring in hepatolenticular degeneration (Case 1).

illegible, and all voluntary movements were performed grotesquely and with much uncontrollable tremor and agitation. There were frequent powerful twisting movements of the trunk and upper limbs. At times these caused him to perspire profusely and cry out in pain. The left arm was usually held in a flexed posture behind his back and the left leg was flexed at hip, knee, and ankle. There was no significant abnormality of power or reflex activity and sensibility was normal. No enlargement of liver or spleen was perceived. His condition rapidly deteriorated while he was in hospital and there were crops of petechiae and purpuric patches over the arms and legs. At times he went into powerful tetanic muscle spasms and his body became drenched with sweat. Opisthotonos was severe at times; speaking and swallowing were impossible. He died in such a "crisis" associated with hyperpyrexia (Figs. 2, 3, and 4). Biochemical findings are tabulated as follows: 


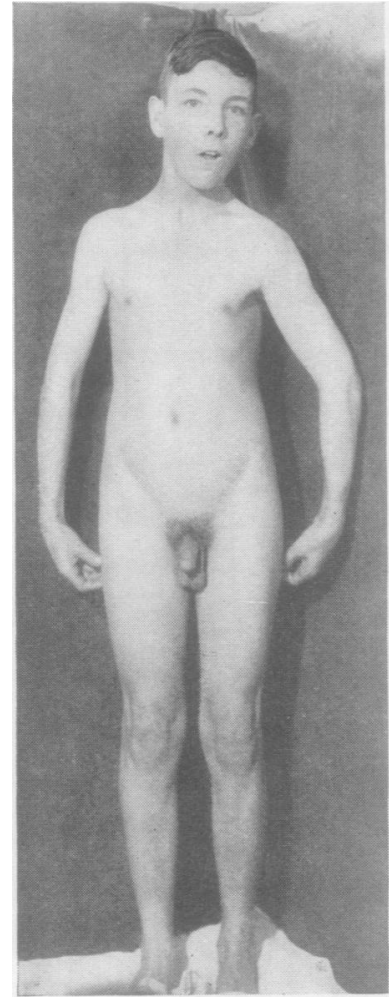

FiG. 2.-Case 1 at the age of 13 years.
Urine.-Albumin varied from a trace to a fairly large amount; no sugar; no trace of bile pigment. Aminoaciduria was found. The patient's parents showed normal amino nitrogen excretion (Table I).

TABLE I

Amino Acid Excretion in 13 Cases of Dijease of the Basal GANGlia

\begin{tabular}{|c|c|c|c|c|c|}
\hline \multicolumn{4}{|c|}{ Diagnosis } & Case No. & $\begin{array}{l}\text { Urinary Amino Nitrogen } \\
\text { Excretion* (mg./24 hr ) }\end{array}$ \\
\hline \multicolumn{4}{|c|}{ Hepatolenticular degeneration } & 1 & 1,005 \\
\hline \multirow[t]{2}{*}{ Dystonia } & $\ldots$ & . & $\ldots$ & 2 & 260 \\
\hline & $\ldots$ & .. & $\ldots$ & 3 & 143 \\
\hline , & . & . & . & 4 & 146 \\
\hline , & . & . & . & 5 & 185 \\
\hline , & $\ldots$ & .. & $\ldots$ & 6 & 205 \\
\hline & & & $\ldots$ & 7 & 300 \\
\hline \multicolumn{3}{|c|}{ Huntington's chorea } & . & 8 & 147 \\
\hline , & ," & . & . & 9 & 394 \\
\hline , , & , & . & . & 10 & 370 \\
\hline & , & .. & $\ldots$ & 11 & 112 \\
\hline Athetosis & . & . & $\ldots$ & 12 & 245 \\
\hline ,', & . & . & . & 13 & 256 \\
\hline Normals $†$ & . & . & . & $14-22$ & 232-438 (av. 332) \\
\hline
\end{tabular}

* In some cases the figure given is the average of more than one estimation

+ T wo of these were the patient's parents: amino N. 386 and 245 respectively.

Renal Function.-Urea clearance was $107 \%$ of the average normal

Blood.-Urea $32 \mathrm{mg} . / 100 \mathrm{ml}$; serum calcium $9.8 \mathrm{mg}$./ $100 \mathrm{ml}$.: platelets 260,000 ; clotting time (Lee and White) 3 min. $45 \mathrm{sec}$. (normal); bleeding time (Duke) $3 \mathrm{~min}$. (normal); serum total protein 6.7 g. $/ 100 \mathrm{ml}$; serum total albumin $4.45 \mathrm{~g}$. $/ 100 \mathrm{ml}$; serum alkaline phosphatase 24.7, 22.0 King-Armstrong units: serum bilirubin $0.2 \mathrm{mg} . / 100 \mathrm{ml}$; thymol turbidity 2 units

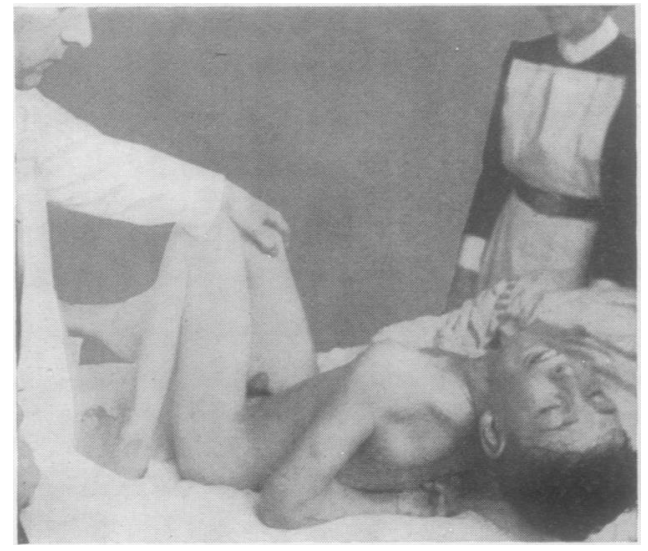

FIGS. 3 and 4.-Powerful generalized muscular spasms in terminal stages of illness (Case 1).

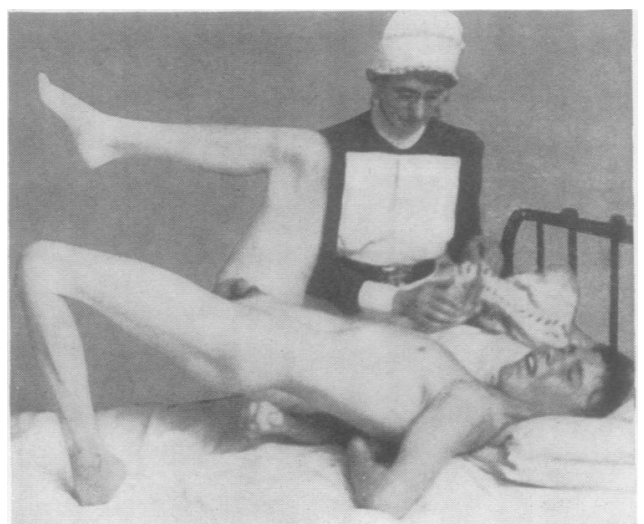


(repeatedly); Kunkel turbidity 8, 7 units ; serum co!loidal gold 000000 ; prothrombin $80 \%$ of average normal ; blood copper $80 \mu \mathrm{g} . / 100 \mathrm{ml}$.

The liver function tests, which were all done within a month of the patient's death, gave normal results except that the phosphatase value was rather high : Sunderman (1942) gives the range of normal values for children as 15-20 King-Armstrong units.

At the post-mortem examination the surface of the liver was found to be nodular (Fig. 5). A large section was prepared and this showed numerous nodules, most of which were about $1 \mathrm{~cm}$. in diameter, with intervening fibrosis (Fig. 6). This section clearly shows that a punch biopsy might not reveal cirrhosis, as it would be quite easy to take the specimen from the centre of one of these nodules. Microscopy revealed cirrhosis (Fig. 7). The spleen was enlarged (300 g.). There was much proliferation of the endothelium of the sinuses and the follicles were atrophic. In the central nervous system, only the putamen was abnormal, showing neuronal degeneration. Acute bronchitis was present in the lungs. The other organs, including the kidney, appeared normal.

After death it was found that the copper content of brain and liver tissue was raised, as shown in Table II. Liver tissue obtained from a woman who died as a result of a head

TABLE II

Copper Content of Tissues in Hepatolenticular Degeneration

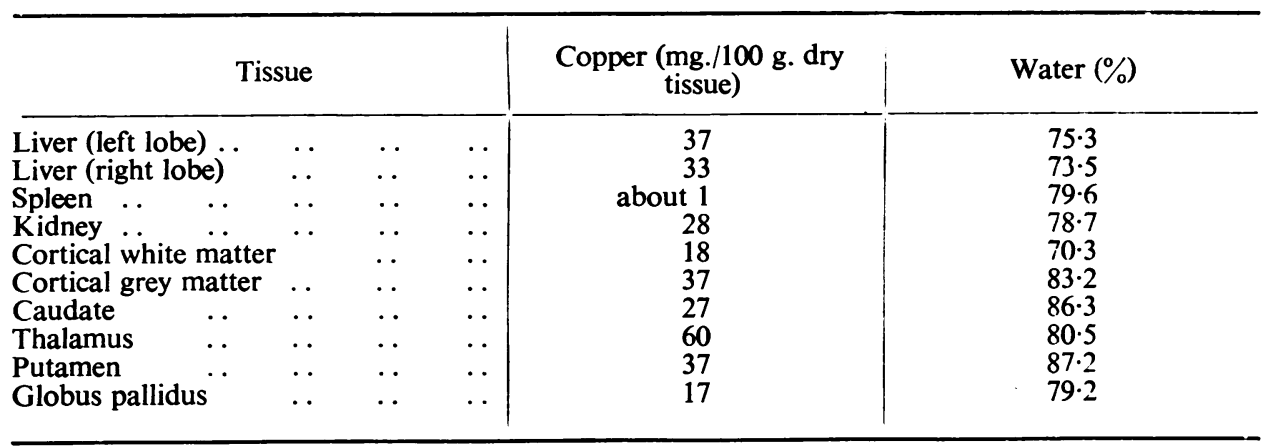

injury was found to contain only $2 \mathrm{mg}$. of copper per $100 \mathrm{~g}$. of dried tissue. Normal values for brain and liver tissue found by Cumings are given on p. 17. In confirmation of the findings of Mandelbrote and his colleagues and of Porter we found that in our case of hepatolenticular degeneration B.A.L. caused an increased excretion of copper in the urine (Table III).

TABLE III

EFFECT OF B.A.L. ON URINARY COPPER EXCRETION IN HePATOlenticulaR DEGENERATION

\begin{tabular}{|c|c|c|c|c|c|}
\hline \multicolumn{4}{|c|}{ Period } & Volume (ml.) & Copper Content $(\mu \mathrm{g})$. \\
\hline $\begin{array}{l}1\left(2 \frac{1}{2} \mathrm{hr} .\right) \\
2(3 \mathrm{hr} .)\end{array}$ & 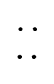 & $\because$ & $\begin{array}{ll}\cdots & \cdots\end{array}$ & $\begin{array}{c}84 \\
140 \\
\text { iniected at end of second }\end{array}$ & $\begin{array}{l}76 \\
98\end{array}$ \\
\hline $\begin{array}{l}3\left(2 \frac{1}{4} \mathrm{hr} .\right) \\
4\left(1 \frac{3}{4} \mathrm{hr} .\right)\end{array}$ & $\begin{array}{l}\ldots \\
\ldots\end{array}$ &.. & $\begin{array}{ll}. & . \\
\cdots & \cdots\end{array}$ & $\begin{array}{r}123 \\
63\end{array}$ & $\begin{array}{r}192 \\
46\end{array}$ \\
\hline
\end{tabular}

Case 4 : Dystonia.-A boy, aged 6 years, was well until 3 years of age, then had a series of convulsions. For two years "his right hand began to go behind his chest" 


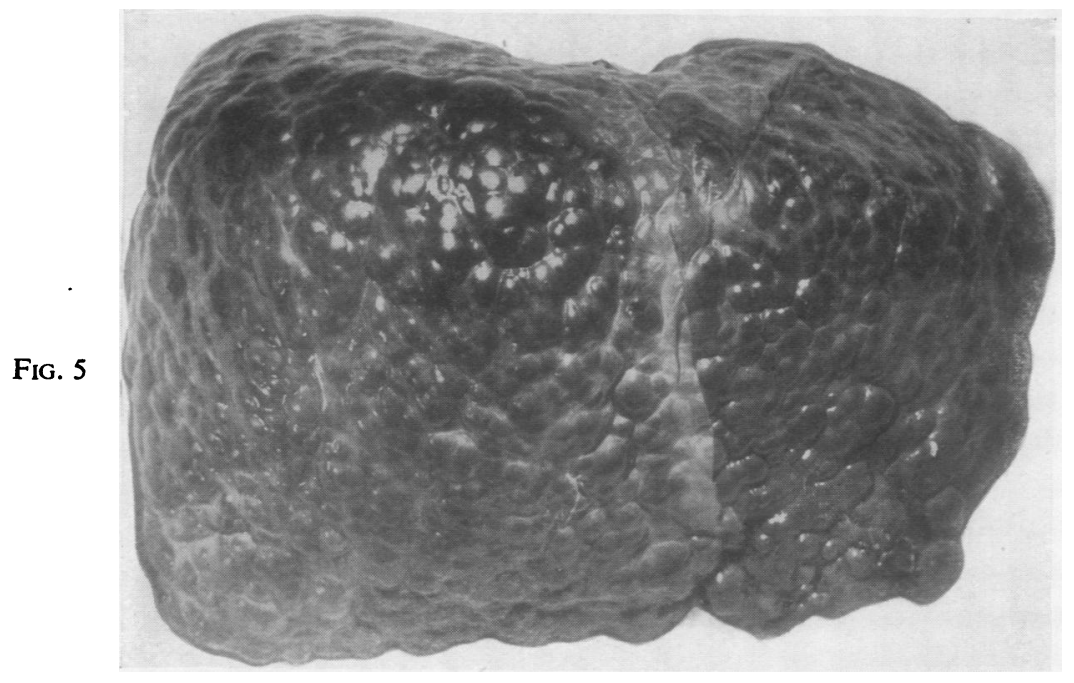

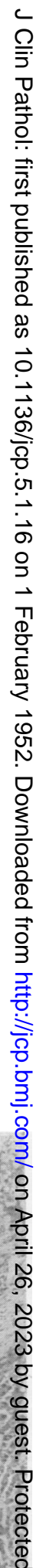

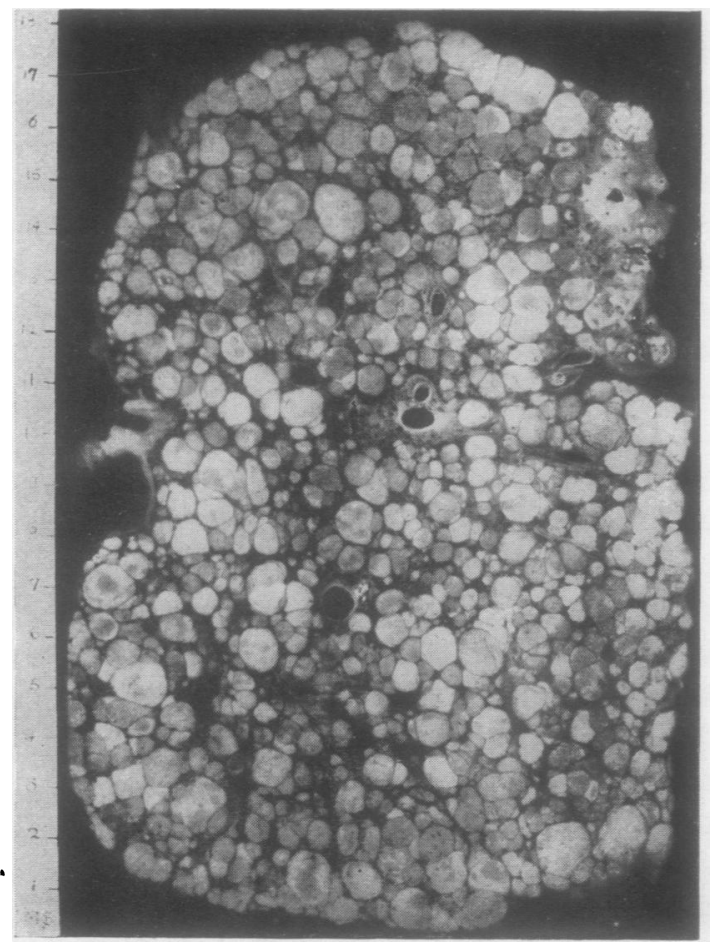

Fig. 6

FIG. 5.-Gross appearance of liver (Case 1).

Fig. 6.-Section of liver of Case 1 prepared by method of Gough and Wentworth (1949).

Fig. 7.-Histological appearance of liver (Case 1).

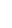


(mother's statement). Then later, " his right foot went funny." He became excitable and difficult. Intelligence appeared normal, but he did not go to school. Speech was normal ; he walked in a jerky, "dancing" fashion, with abrupt flexion movements of the right leg. The right hand was flexed behind his back, and he showed occasional twisting movements of the trunk, and generalized tremors. Grimacing and giggling were frequently noted. There was no evidence of liver disease, the eyes were normal, and no history of jaundice was elicited. His behaviour and stance were similar to those of Case 1. An air encephalogram was normal. Muscular hypertonicity on the right and left sides, more marked on the right, was present. Amino acid excretion was normal. The blood copper level was normal. Renal function tests were normal.

Case 7 : Dystonia. - This woman, aged 32 years, had a normal family history. She had jaundice at the age of 10 years. Since 11 years she has had progressive dystonia culminating in generalized muscular rigidity, with incoherent speech, dysphagia, generalized tremors, and powerful torsion movements of the neck, trunk, and limbs. She was very emotional, and would laugh and cry with great ease and readiness. The facial appearance and history of jaundice raised the possibility of hepatolenticular degeneration. Her face was set in a "smiling" manner as in Case 1. Renal and liver function tests were normal. The blood copper level was normal. Liver biopsy was performed, but there was insufficient material obtained for adequate examination. Amino acid excretion was normal.

TABLE IV

BloOd and Urine Copper EXCRetion In Six CASES

\begin{tabular}{c|c|c}
\hline Case No. & $\begin{array}{c}\text { Blood Copper } \\
(\mu \mathrm{g} . / 100 \mathrm{ml} .)\end{array}$ & $\begin{array}{c}\text { Urine Copper } \\
(\mu \mathrm{g} . / 24 \text { hours })\end{array}$ \\
\hline 1 & 80 & $760^{*}$ \\
2 & 115 & 40 \\
3 & 105 & 20 \\
4 & 135 & 30 \\
5 & 90 & 60 \\
13 & 100 & \\
\hline
\end{tabular}

* Calculated from $5 \frac{1}{2}-\mathrm{hr}$. period (see Table III).

\section{Comment}

It was confirmed that in this series only in the patient with hepatolenticular degeneration was there a disturbance of amino acid excretion. In this case liver function tests revealed no abnormality (with the exception of the raised phosphatase) yet when the patient died severe hepatic cirrhosis was present. This suggests that in attempting to explain the origin of the amino-aciduria in this disease the liver must not be assumed to be normal because such tests give normal results. In contrast to eight of the nine cases reported by Sweet, Gray, and Allen (1941) our case of hepatolenticular degeneration showed a normal serum colloidal gold reaction. These results as a whole might have been interpreted as indicating that in our case the amino-aciduria pointed to some constitutional metabolic error, and was not a result of liver disease.

The absence of amino-aciduria may be helpful in the diagnosis of doubtful cases, as in our Cases 4 and 7. Both patients were facile and emotional ; they giggled and smiled abnormally. In Case 4 there was the same complaint that "the right arm goes behind his back all the time." In Case 7 there was a history of jaundice and 
the facial appearance was not unlike that of hepatolenticular disease. The copper concentration of the blood was normal in each case.

The significance of the disturbance of copper metabolism in hepatolenticular degeneration remains a mystery.

\section{Summary}

Urinary amino nitrogen excretion was measured in 13 people with disease of the basal ganglia and in nine normal people. It was raised only in a boy with hepatolenticular degeneration, neither of whose parents had amino-aciduria.

In this case, liver function tests in the month before death showed little evidence of liver disease. At necropsy hepatic cirrhosis was found.

This patient excreted large amounts of copper in the urine. Administration of B.A.L. increased the copper output.

Brain and liver tissue obtained at necropsy contained excessive amounts of copper.

We wish to thank the following: Messrs. G. R. Armstrong and H. A. Griffiths for the photographs, Miss Nansi Gwynne for the painting of the eye, Dr. A. G. Heppleston for the post-mortem examination, Mr. J. E. Wentworth for preparing the large section of the liver, and Professor J. Gough for his help and encouragement.

\section{REFERENCES}

Aggeler, P. M., Howard, J., Lucia, S. P., Clark, W., and Astaff, A. (1946). Blood, 1, 22.

Albanese, A. A., and Irby, V. (1944). J. biol. Chem., 153, 583.

Ames, S. R., and Risley, H. A. (1948). Proc. Soc. exp. Biol., N.Y., 68, 131.

Cooper, A. M., Eckhardt, R. D., Faloon, W. W., and Davidson, C.S. (1950). J. clin. Invest., $29,265$.

Cumings, J. N. (1948). Brain, 71, 410.

- (1951). Ibid., 74, 10.

Eckhardt, R. D., Cooper, A. M., Faloon, W. W., and Davidson, C. S. (1948). Trans. N.Y. Acad. Sci., 10 (Series 2), 284.

Eden, A., and Green, H. H. (1940). Biochem. J., 34, 1202.

Glazebrook, A. J. (1945). Edinb. med. J., 52, 83.

Gough, J., and Wentworth, J. E. (1949). J. roy. micr. Soc., 69, 231.

Haurowitz, F. (1930). Hoppe-Seyl. Z., 190, 72.

Howe, P. E. (1921). J. biol. Chem., 49, 93.

King, E. J. (1946). Micro-analysis in Medical Biochemistry. London.

Kunkel, H. G. (1947). Proc. Soc. exp. Biol., N.Y., 66, 217.

Maclagan, N. F. (1944a). Brit. J. exp. Path., 25, 15.

- (1944b). Ibid., 25, 234.

Mandelbrote, B. M., Stanier, M. W., Thompson, R. H. S., and Thruston, M. N. (1948). Brain, 71, 212.

Pollak, H. (1947). In Recent Advances in Clinical Pathology, ed. S. C. Dyke, p. 147. London.

Pope, C. G., and Stevens, M. F. (1939). Biochem. J., 33, 1070.

Porter, H. (1949). J. Lab. clin. Med., 34, 1623.

Quick, A. J. (1945). Amer. J. clin. Path., 15, 560.

Sunderman, F. W. (1942). Ibid., 12, 404.

Sweet, W. H., Gray, S. J., and Allen, J. G. (1941). J. Amer. med. Ass., 117, 1613.

Uzman, L., and Denny-Brown, D. (1948). Amer. J. med. Sci., 215, 599. 